Nepal Journal of Science and Technology Vol. 14, No.2 (2013) 123-130

\title{
Production, Purification and Characterization of Hemicellulose from Penicillium janthinellum 3CHP
}

\author{
S. Adhikari and B.S. Chadha \\ Department of Microbiology, Guru Nanak Dev University, Amritsar, India \\ e-mail: sanadh26@gmail.com
}

\begin{abstract}
Penicillium janthinellum 3CHP, a mesophilic fungal strain, isolated from the pine forest of Simla hill was found to produce an array of hemicelluloses when grown in urea medium with sorghum straw as the carbon source. For purification these enzymes, were subjected to ion exchange chromatography. The active fractions pertaining to á-arabinofuranosidase obtained from it were pooled and concentrated using PM-10 (10 KDa cut off) fitted into an Amicon cell and further purified by gel filtration chromatography. Active fractions which exhibited high á-arabinofuranosidase activity in gel filtration chromatography were again pooled, concentrated and analyzed by SDS PAGE and zymogram development using L-umbelliferyl arabinofuranoside as substrate. Two isoforms of á-arabinofuranosidase were observed with molecular weight of approximately 60 and $80 \mathrm{KDa}$ respectively. á-arabinofuranosidase, was further characterized with respect to various parameters such as temperature, $\mathrm{pH}$, effect of various metal ions and chemicals, substrate specificity, and thermo-stability.
\end{abstract}

Key words: $\alpha$-L-arabinofuranosidase, gel filtration chromatography, ion-exchange chromatography, zymogram

\section{Introduction}

Lignocellulose is a complex polymeric material composed of $40-60 \%$ cellulose, $20-40 \%$ hemicelluloses and $15-25 \%$ lignin (Spano et al. 1980). Hemicelluloses are more heterogeneous and the second most abundant organic structure which refers to a group of homoand hetero- polymers consisting of xylopyranose, mannopyranose, glucopyranose and galactopyranose main chains with a number of substituents (Jeffries 1994). Xylan and glucomannan are the two main types of hemicellulose (Viikari et al. 1992). Xylan is a complex and major heteropolysaccharide constituent of hemicellulose which is present in the form of arabinoglucuronoxylan in softwood and grasses, and as $O$-acetyl-4- $O$-methylglucurono- $\beta$-D-xylan in hardwood (Laine 2005). This heteropolymer containing a backbone of $\beta-1,4$ linked xylopyranosyl units is substituted with L-arabinosyl, acetyl, feruloyl, $p$ coumaroyl and glucoronyl residues (Howard et al. 2003). The frequency and the composition of the branches in isolated xylans are dependent upon their source and method of extraction (Wong et al. 1988). Glucomannan and galactomannan, the major hemicellulolytic components of softwoods, consist of a $\beta$-1,4-linked D-mannose backbone that is substituted with $\quad \alpha$-1,6-linked $\quad D$-galactose. While galactoglucomannan also contains â-1,4-linked D-glucose residues (Ronald \& Jaap 2001).

Due to the heterogeneity and complex chemical nature of hemicellulose, its hydrolysis into simpler constituents (monomers, dimers or oligomers) requires the action of a wide spectrum of enzyme with diverse catalytic specificaties and modes of action Endo-1,4âxylanase cleaves the glycosidic bonds in the xylan backbone, bringing about a reduction in the degree of polymerization of the subtrate. A variety of microorganisms are reported to produce endoxylanases that can degrade $\beta-1,4$ xylan in a random fashion, yielding a series of linear and branched oligosachharide fragments (Kormelink et al. 1993, Bhat \& Hazlewood 2001). Exo-1,4- $\beta$-D-xylosidase catalyzes the hydrolysis of xylooligosaccharides by removing successive D-xylose residues from the non-reducing end. $\alpha-\mathrm{L}-$ Arabinofuranosidase hydrolyzes the terminal, nonreducing arabinofuranosyl groups of arabinans, arabino-xylans, and arabinogalactans. $\alpha$-D-glucuronidase is required for the hydrolysis of 
$\alpha$-1,2-glycosidic linkages between xylose and D-glucuronic acid. Esterases break the bonds of xylose to acetic acid (xylan acetyl esterase), arabinose side chain residues to ferulic acid (feruloyl esterase), arabinose side chain residues to $p$-coumaric acid ( $p$-coumaroyl esterase). Cleavage of acetyl, feruloyl and $p$-coumaroyl groups from the xylan are helpful in removal of lignin. Hemicellulases have various applications from biotechnological and industrial point of view (Nigam 2011). Potential applications of hemicellulases include biobleaching of wood pulp, treating animal feed to increase digestibility, processing food to increase clarification, converting lignocellulosic substances to feed-stock and fuels, as dietary supplement to treat poor digestion and pharmaceuticals etc. Interestingly, the hemicellulases required for each of the above processes are of different characteristics and therefore, the choice of hemicellulase and the producing microorganisms could differ. Nevertheless, few of the microbial strains produce versatile enzymes that can perform optimally well for different process applications. Recently, the interest generated on functional foods and possible use of xylooligosaccharides as pre-biotics is another area where the role of hemicellulases needs to be evaluated (Bhat 1998). Because of these applications, hemicellulases possess tremendous commercial potential and need to isolate new sources of hemicellulases and their characterization is the thrust arena that should be continued with interest. Hemicellulases are produced by many bacteria and fungi. From an industrial point of view, filamentous fungi are interesting producers of these enzymes. Among various filamentous fungi, Penicillium sp. have also been exploited for the production of hemicellulases. According to Chavez et al. (2004), Penicillia constitute a rich source of enzymes for the biodegradation of hemicelluloses. In the current study, we have produced $\alpha$-L-arabinofuranosidase from $P$. janthinellum, which has been characterized with regard to various parameters.

\section{Methodology \\ Culture of the fungus}

A mesophilic fungal strain Penicillium janthinellum $3 \mathrm{CHP}$ was used in the experiment. Its culture was grown at $30^{\circ} \mathrm{C}$ on PDA medium. A spore suspension from a five day old slants of the culture was prepared in 6.0 $\mathrm{ml}$ of sterilized water blank containing Tween $80(0.1 \%$ $\mathrm{w} / \mathrm{v}$ ) as surfactant.

\section{Enzyme production}

Sorghum straw was cut into small pieces, dried in an oven at $50^{\circ} \mathrm{C}$ and ground to approximately $2 \mathrm{~mm}$ size. Solid state fermentation (SSF) was carried out in Erlenmeyer flasks $(250 \mathrm{ml})$ that contained sorghum straw $(5 \mathrm{~g})$ as carbon source and $15 \mathrm{ml}$ of urea medium of the following composition (\%w/v); $\left(\mathrm{NH}_{4}\right)_{2} \mathrm{SO}_{4} 1.0$; Urea 0.3; $\mathrm{KH}_{2} \mathrm{PO}_{4} 0.3 ; \mathrm{MgSO}_{4} 0.05 ; \mathrm{CaCl}_{2} 0.05 ; \mathrm{K}_{2} \mathrm{HPO}_{4}$ 0.05 . The medium was sterilized at 15 psi for 15 minutes at $121^{\circ} \mathrm{C}$. Prior to sterilization, the $\mathrm{pH}$ of the medium was adjusted to 7.0. Urea, being labile to heat, was separately cold-sterilized using membrane filter of size $0.2 \mu \mathrm{m}$. The production medium was inoculated with 2 $\mathrm{ml}$ of spore suspension prepared as above, and incubated in water-saturated atmosphere at atmosphere at $30^{\circ} \mathrm{C}$ for 5 days. The enzyme was harvested by adding $50 \mathrm{ml}$ of sodium citrate buffer ( 50 $\mathrm{mM}, \mathrm{pH} 6.0$ ) to the flasks and the contents were mixed thoroughly with the help of sterile glass rod. Then it was kept under shaking conditions on a rotary shaker (ORBITEK) at $140 \mathrm{rpm}$ for $30 \mathrm{~min}$. The fermented slurry was filtered through muslin cloth and centrifuged at $10,000 \mathrm{rpm}$ for $10 \mathrm{~min}$ to remove the debris. Resultant clear supernatant was added with EGTA-EDTA mix (each@1 mM) and PMSF (phenyl methyl sulphonyl fluoride, $0.2 \mathrm{M}$ ) to inhibit protease activity and sodium azide $(0.02 \% \mathrm{w} / \mathrm{v})$ to avoid further contamination. The enzyme extract was then stored in sterilized vials at $20^{\circ} \mathrm{C}$ and it was used for enzyme assay whenever necessary.

\section{$\alpha$-L-arabinofuranosidase assay}

$\alpha$-L- arabinofuranosidase activity of the crude extract as well as fractions obtained from ion-exchange and gel filtration chromatography was determined in the following way.

The substrate $p N P-\alpha$-arabinofuranoside $(3 \mathrm{mM})$ was used to assay $\alpha$-L- arabinofuranosidase (EC 3.2.1. 55). The reaction mixture containing $25 \mu \mathrm{l}$ of enzyme, $25 \mu \mathrm{l}$ of substrate solution and $50 \mu \mathrm{l}$ of sodium acetate buffer (50 mM, pH 5.0) were incubated at $50^{\circ} \mathrm{C}$ for 30 minutes in dark. The reaction was terminated using $100 \mu \mathrm{l}$ of $\mathrm{NaOH}$ glycine buffer $(400 \mathrm{mM}, \mathrm{pH} 10.8)$ and the developed colour was read at $405 \mathrm{~nm}$ using ELISA reader (MULTISKAN; Labsystems).

$$
\text { Activity }=\underline{\text { Optical Density(OD)xDilution Factor x } 45.432}
$$$$
104.3
$$ 
Where $\mathrm{OD}=$ Mean of reaction mixtures-(substrate blank + enzyme blank)

In case of active fractions obtained after ion-exchange chromatography and gel filtration chromatography, $\alpha$-L- arabinofuranosidase activity was determined in the same way except that the reaction mixture was incubated at $50^{\circ} \mathrm{C}$ in dark for an hour.

\section{Estimation of protein}

The protein in the fractions eluted from ion exchange chromatography as well as gel filtration chromatography was determined by protein-dye binding method given by Lowry.

\section{Purification of hemicellulases Desalting}

Enzyme extract was concentrated ten times using PM10 membrane (10 K Da cut off) fitted into an Amicon cell. Further washing was given to it with the help of sterilized milli $Q$ water to remove any salts present in the enzyme extract.

\section{Ion-exchange chromatography}

Enzyme extract $(70 \mathrm{mg}$ ) was loaded onto source $15 \mathrm{Q}$ column and was eluted under isocratic conditions followed by linear gradient of $1 \mathrm{M} \mathrm{NaCl}$ in $0.020 \mathrm{M}$ Tris $\mathrm{HCl}$ at a flow rate of $0.5 \mathrm{ml}$ per minute. All the fractions $(5 \mathrm{ml}$ each) were analyzed for $\alpha-\mathrm{L}$ arabinofuranosidase activity as well as for protein. Active fractions corresponding to the maximum $\alpha$-Larabinofuranosidase obtained during $\mathrm{NaCl}$ gradient elution were pooled, desalted and concentrated with $50 \mathrm{mM}$ sodium acetate buffer $\mathrm{pH} 5$ having $0.15 \mathrm{M}$ $\mathrm{NaCl}$, using PM-10 membrane (10 K Da cut off) fitted into an Amicon cell and concentrated enzyme was subjected to gel filtration chromatography for further purification of the enzyme.

\section{Gel filtration chromatography}

One ml of enzyme extract was applied to the Sephacryl HR 200 (Sigma) matrix column and eluted with two bed volumes of sodium acetate buffer $(50 \mathrm{mM}, \mathrm{pH} 5.0)$ containing $\mathrm{NaCl}(0.15 \mathrm{M}, \mathrm{pH} 5.0)$ at a flow rate of 0.2 $\mathrm{ml}$ per minute. The active fractions collected ( $2 \mathrm{ml}$ each) were assayed for $\alpha$-L-arabinofuranosidase activity as well as for protein and they were further pooled, concentrated and used for SDS-PAGE and zymogram analysis and for the characterization of the enzyme.

\section{Molecular weight determination by SDS- PAGE}

The homogeneity and molecular weight of the enzyme was determined by using $12 \%$ SDS-PAGE gel (Laemmli, 1970) using Bio-Rad Mini-Protein II electrophoresis unit. Protein bands in the gel were visualized by silver staining method (Blum et al. 1987).

\section{Zymogram analysis}

Zymogram analysis of the hemicellulases obtained in SDS PAGE was performed using modified method of Taylor et al. (2006). SDS-PAGE gels were further renatured by incubating them in refolding buffer [20 $\mathrm{mMN}$-2-hydroxyethyl piperazine- $\mathrm{N}$-2-ethanesulfonic acid (pH 6.8), 2.5\% Triton X-100, $2 \mathrm{mM}$ Dithiothreitol (DTT), and $2.5 \mathrm{mM} \mathrm{CaCl}_{2}$ ] for 1 hour at room temperature and held at $4^{\circ} \mathrm{C}$ overnight in fresh refolding buffer. The gels were thoroughly washed 56 times in distilled water and overlaid with the substrate solution prepared by dissolving $1.8 \mathrm{mg}$ of the substrate, á-L-umbelliferyl arabinofuranoside, in DMSO $(1 \mathrm{ml})$ and $1 \mathrm{ml}$ of sodium acetate buffer $(50$ $\mathrm{mM}, \mathrm{pH}$ 5.0). The bands were observed using UVtransillluminator (Bio- Rad).

\section{Characterization of the enzyme}

The active fractions obtained after gel filtration chromatography corresponding to $\alpha-\mathrm{L}$ arabinofuranosidase which gave purified bands on SDS-PAGE and zymogram analysis were further characterized for their temperature and $\mathrm{pH}$ optima, effect of metal ions and chemicals, various substrate specificities and thermostability.

\section{Results and Discussion}

In the present study, production and purification of hemicellulases was carried out from $P$. janthinellum 3 CHP. One of the hemicelluloses, $\alpha-\mathrm{L}$ arabinofuranosidase, was purified and characterized for its different parameters.

\section{Ion-exchange chromatography}

The results below (Fig. 1) show the elution profile of $\alpha$-L-arabinofuranosidase activity. The chromatogram shows that $\alpha$-L-arabinofuranosidase eluted as two distinct peaks (AF I and AF II) under isocratic and $\mathrm{NaCl}$ gradient conditions, respectively. Fractions showing maximum $\alpha$-L-arabinofuranosidase activities were pooled, concentrated and used for further purification by gel filtration chromatography. 


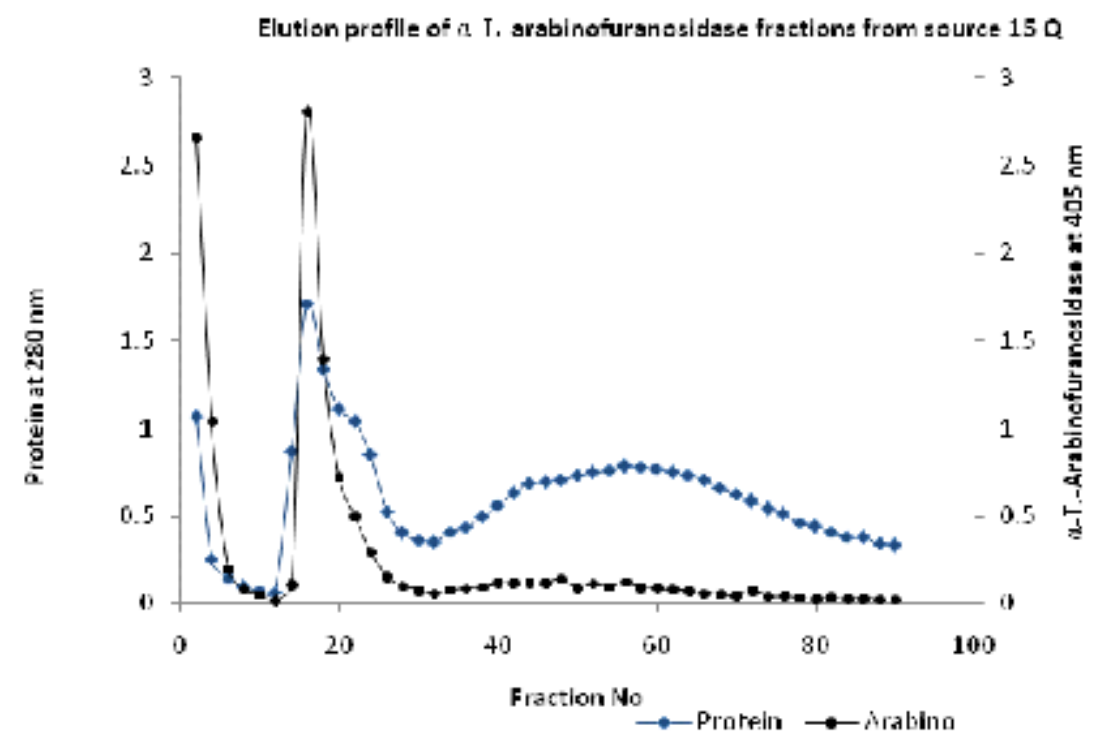

Fig.1. Elution profile for $\alpha$-L-arabinofuranosidase active fractions from ion-exchange chromatography

\section{Gel filtration chromatography}

Fig. 2 shows different chromatograms depicting elution profiles for $\alpha$-L-arabinofuranosidase along with its respective protein in 112 different fractions obtained after gel filtration chromatography. The fractions exhibiting high $\alpha$-L-arabinofuranosidase activity were subjected to SDS-PAGE analysis to assess the production of arabinofuranosidase. The fractions from 26 to 48 were found to contain purified $\alpha-\mathrm{L}-$ arabinofuranosidase enzyme (Fig. 2). Fig. 3(a) shows the SDS-PAGE of the concentrated active enzyme fractions ( $\alpha$-L-arabinofuranosidase) after gel filtration chromatography and Fig. 3(b) shows the activity staining of the renatured gel using $\alpha$-L-umbelliferyl arabinofuranoside as substrate. The results show that these fractions contained two $\alpha$-L-arabinofuranosidase isoforms on SDS-PAGE. The bands showed fluorescence when reacted with $\alpha$-L-umbelliferyl arabinofuranoside indicating the presence of $\alpha-\mathrm{L}$ arabinofuranosidase activity in these bands. The protein bands were of approximately 63 and $80 \mathrm{KDa}$ respectively.

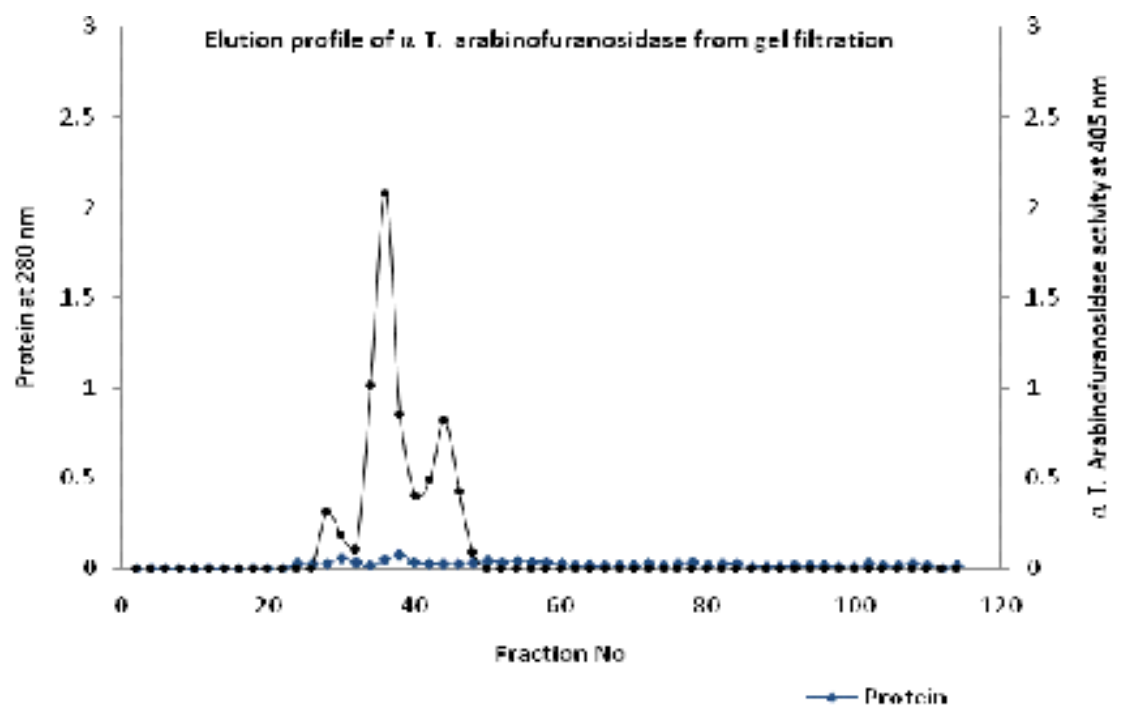

Fig.2. Elution profile for $\alpha$-L-arabinofuranosidase active fractions from gel filtration chromatography 

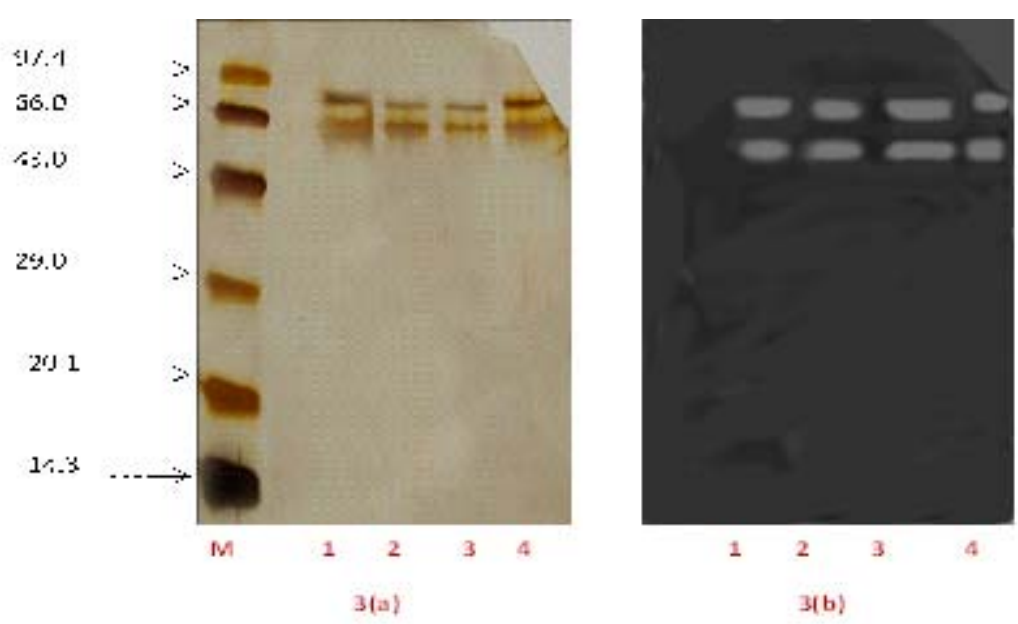

Fig. 3(a). SDS-PAGE of á-L-arabinofuranosidase

Fig. 3(b). Zymogram to detect á-L-arabinofuranosidase

\section{Characterization of purified $\alpha-L$ - arabinofuranosidase}

After having $\alpha$-L-arabinofuranosidase purified, an attempt was made to thoroughly characterize this enzyme with respect to various parameters.

\section{Effect of temperature}

Fig.4 shows the effect of different temperatures on $\alpha$-L-arabinofuranosidase activity. It was observed that the activity increased when the temperature increased from $20^{\circ} \mathrm{C}$ to $50^{\circ} \mathrm{C}$ and decreased steadily thereafter. The enzyme though showed appreciable activity at $80^{\circ} \mathrm{C}$ but total loss of activity was observed at $90^{\circ} \mathrm{C}$. Optimum temperature for the enzyme was also found to be $50^{\circ} \mathrm{C}$ for $P$. purpurogenum (Ioannes et al. 2000) and P. sp. LYG0704 (Lee et al. 2011).

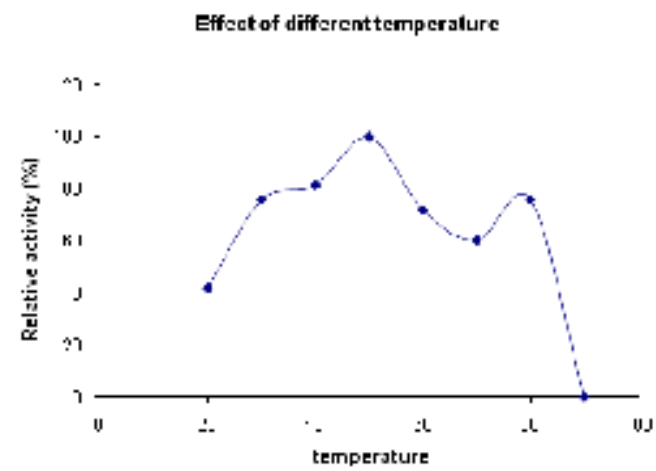

Fig. 4. Effect of different temperatures on $\alpha$-L-arabinofuranosidase

\section{Effect of pH}

Results in Fig. 5 decipher the effect of different $\mathrm{pH}$ on á-L-arabinofuranosidase activity. The enzyme was found to be completely inactive at $\mathrm{pH} 3.0$ and 4.0. The enzyme activity was found to be optimum between $\mathrm{pH}$ 6.0 and 7.0. The activity declined beyond $\mathrm{pH}$ 7.0. Gilead and Shoham (1995) reported that $\alpha$-Larabinofuranosidase activity was maximum in Bacillus stearothermophilus at $\mathrm{pH}$ 5. 5-6.0 where as the optimum $\mathrm{pH}$ for the same enzyme was found to be 4.0 in $P$. purpurogenum (Ioannes et al. 2000). Yan et al. (2012) reported optimum $\mathrm{pH}$ for $\alpha$-L-arabinofuranosidase from Chaetomium sn. was 5.0.

$$
\text { errect or tifterent ph }
$$

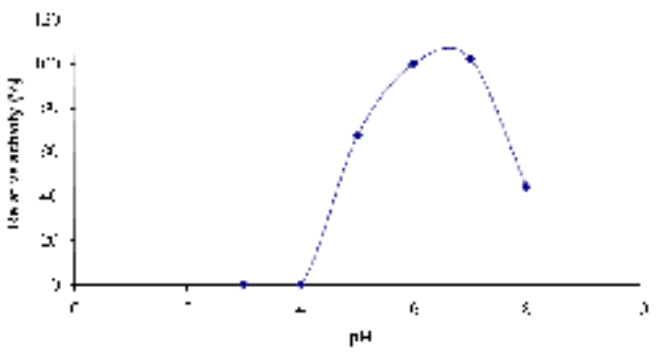

Fig. 5. Effect of different $\mathrm{pH}$ on á-L-arabinofuranosidase

\section{Effect of metal ions and chemicals}

The effect of various metal ions and chemicals $(5 \mathrm{mM})$ is elucidated in Fig. 6. Various metal ions and chemicals $(5 \mathrm{mM})$ were found to positively modulate the activity of $\alpha$-L-arabinofuranosidase. Presence of metal ions $\mathrm{Mg}$, $\mathrm{Mn}, \mathrm{K}, \mathrm{Zn}, \mathrm{Cu}, \mathrm{Fe}$ as well as reducing agent DTT also positively influenced the activities of the enzyme. In addition, reducing agent mercaptoethanol as well as 
chelating agent EDTA also showed positive influence on the enzyme activity. Higher activity of the enzyme in presence of mercaptoethanol and DTT indicates the presence of thiol groups in their active site.
Increased enzyme activity in presence of reducing agents like mercaptoethanol and DTT may be due to suitable changes in conformation of protein (Badhan et al. 2007).

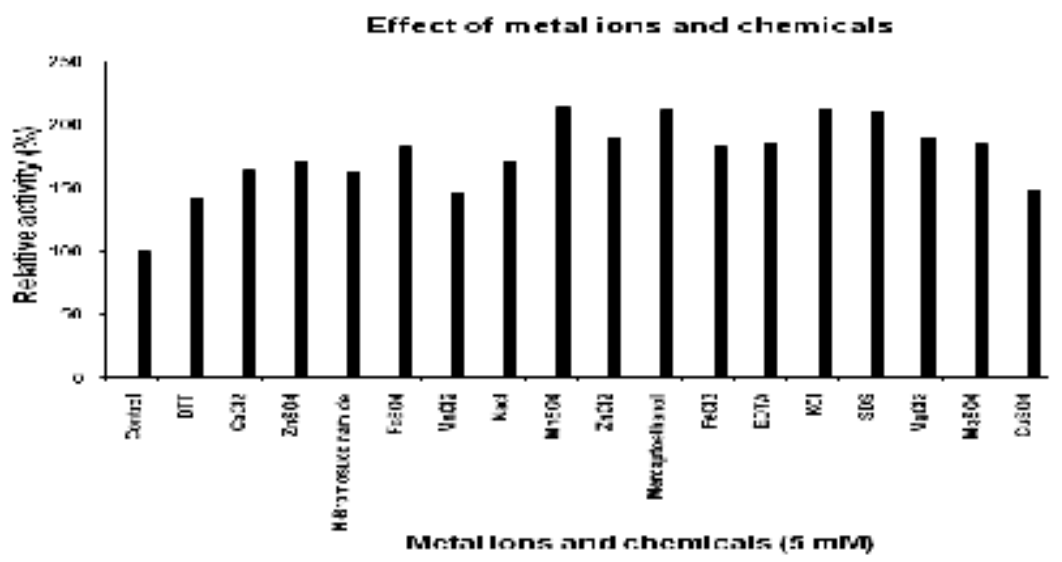

Fig.6. Effect of different metal ions and chemicals $(5 \mathrm{mM})$ on $\alpha$-L- arabinofuranosidase

\section{Substrate specificity}

Table 1. reveals the effect of various $p$ NP-substituted substrates on $\alpha$-L-arabinofuranosidase activity. Except for $p \mathrm{NP}-\alpha$-L-arabinofuranoside, the enzyme showed low activity against other $p N P$-substituted substrates. The enzyme did not exhibit any activity with $p$ NPPalmitate and $p$ NP-Galactopyaranoside and showed negligible activity with $p$ NP-Mannopyranoside. The effect of $p$ NP-Lactopyranoside and $p$ NP-Cellobioside was almost equal on the enzyme activity though the effect was quite low compared to $p \mathrm{NP}-\alpha-\mathrm{L}-$ arabinofuranoside. This is in commensurate with the data obtained by Gilead and Shoham (1995) who reported that $\alpha$-L-arabinofuranosidase from Bacillus stearothermophilus T-6 did not show any activity with $p$ NP-Palmitate, $p$ NP-Galactopyaranoside and $p$ NPMannopyranoside.

Table1. Substrate specificities of $\alpha$-L-arabinofuranosidase

\begin{tabular}{|c|c|}
\hline Substrates & Relative activity (\%) \\
\hline$p$ NP- $\alpha$-L-arabinofuranoside & 100 \\
\hline$p$ NP- $\beta$-xylopyranoside & 1.87 \\
\hline pNP-Lactopyranoside & 15.69 \\
\hline$p$ NP-Cellobioside & 15.30 \\
\hline pNP-Glucopyranoside & 4.14 \\
\hline$p$ NP-Mannopyranoside & 1.28 \\
\hline$p$ NP-Galactopyranoside & 0.59 \\
\hline$p$ NP-Acetate & 18.49 \\
\hline$p$ NP-Myristate & 4.93 \\
\hline$p$ NP-Butyrate & 14.88 \\
\hline$p$ NP-Stearate & 8.88 \\
\hline pNP-Palmitate & 0.19 \\
\hline
\end{tabular}

\section{Thermostability}

The results in Fig. 7 and 8 show that the enzyme, $\alpha$-Larabinofuranosidase, was apparently stable at $40^{\circ} \mathrm{C}$ and $50^{\circ} \mathrm{C}$ at $\mathrm{pH} 7.0$ and showed no loss of activity even after 90 minutes of incubation. The enzyme activity was lost to some extent after longer incubation. The loss of activity was comparatively more at $\mathrm{pH} 6.0$ as compared to $\mathrm{pH}$ 7.0. This result is similar to the data reported previously by Singh et al. (2000) on Thermomyces lanuginosus. They had reported that the enzyme $\alpha$-L-arabinofuranosidase from $T$. lanuginosus was quite stable at $50^{\circ} \mathrm{C}$ at $\mathrm{pH} 5.0$.

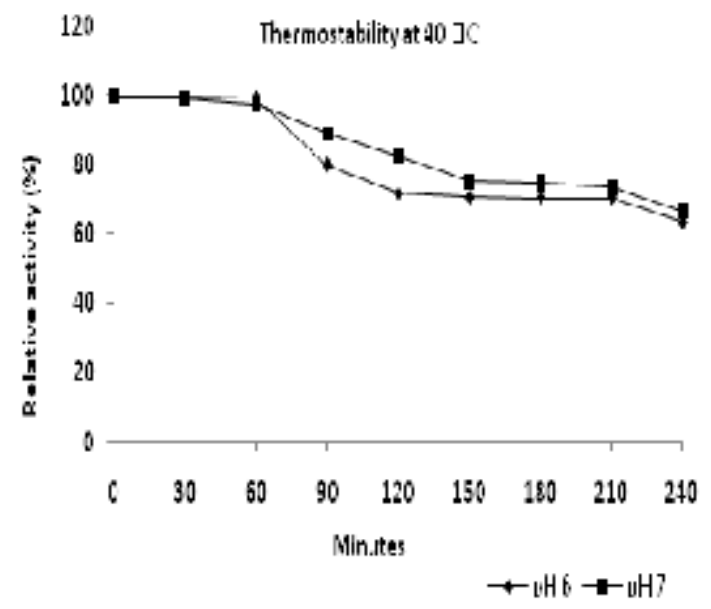

Fig. 7. Thermostability of $\alpha$-L-arabinofuranosidase at $40^{\circ} \mathrm{C}$, pH 6.0 and $\mathrm{pH} 7.0$ 


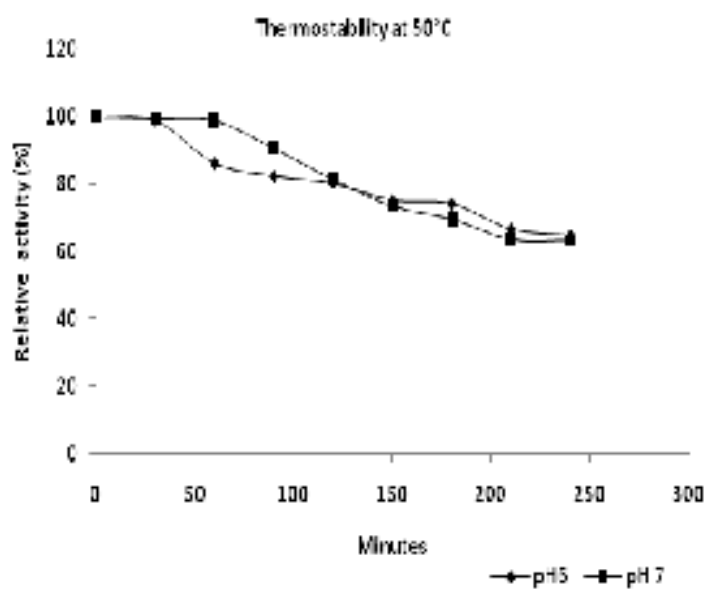

Fig. 8. Thermostability of $\alpha$-L-arabinofuranosidase at $50^{\circ} \mathrm{C}$, pH 6.0 and $\mathrm{pH} 7.0$

\section{Acknowledgements}

We would like to acknowledge Amandeep Kaur, Manju Sharma, and the entire faculties of the Department of Microbiology, Guru Nanak Dev University, Amritsar, Punjab, India for their support in this research.

\section{References}

Badhan, A. K., B.S. Chadha and H. S. Saini. 2007. Purification of the alkalophilic xylanases from Myceliophthora sp. IMI 387099 using celluolosebinding domain as an affinity tag. World J. Microbial. Biotechnol. 24: 973-981.

Bhat, M. K. 1998. Oligossaccharides as functional food ingredients and their role in improving nutritional quality of human food and health. Recent Research Developments in Agricultural and Food Chemistry 2:787-802.

Bhat, M. K. and G.P. Hazlewood. 2001. Enzymology and other characteristics of cellulases and xylanases. Enzymes in Farm Animal Nutrition 7:11-13.

Blum, H., H. Beier and H.J. Gross. 1987. Improved silver staining of plant proteins, RNA and DNA in polyacrylamide gels. Electrophoresis 8:93-99.

Chávez, R., P. Bull and J. Eyzaguirre. 2004. The xylanolytic enzyme system from the genus Penicillum. Journal of Biotechnology 123:413-433.

Gilead, S. and Y. Shoham 1995. Purification and characterization of á-L-arabinofuranosidase from Bacillus stearothermophilus T-6. Applied and Environmental Microbiology. 61:170-174.

Howard, R. L., E. Abotsi, V.R. Jansen and S. Howard. 2003. Lignocellulose biotechnology: issues of bioconversion and enzyme production. Afr. J. Biotechnology 2:602-619.
Ioannes, D. P., A. Peirano, J. Steiner, and J. Eyzaguirre, 2000. An á-L-arabinofuranosidase from Penicillium purpurogenum: production, purification and properties. Journal of Biotechnology 76:253-258.

Jeffries, T. W. 1994. Biodegradation of lignin and hemicelluloses. Biochem. Microb. Degrad. 3:233-277.

Kormelink, F. J., H. Gruppen, R.J. Vietor and A.G. Voragen. 1993. Mode of action of the xylan-degradingn enzymes from Aspergillus awamori on alkali-extractable cereal arabinoxylans. J. Biotechnol. 27:249-265.

Laemmli, U. K. 1970. Cleavage of structural proteins during the assembly of the head of bacteriophage T4. Nature 227:680-685.

Laine, C. 2005. Structures of hemicelluloses and pectins in wood and pulp. Ph.D. thesis, Helsinki University of Technology, KCL, Espoo, Finland.

Lee, D.S., S.G. Wi, Y. G. Lee, E. J. Cho, B.Y. Chung, and H.G. Bae. 2011. Characterization of a new á-Larabinofuranosidase from Penicillium sp. LYG 0704, and their application in lignocelluloses degradation. $\mathrm{Mol}$ Biotechnol. 49 (3):229-39.

Matsuo, N., S. Kaneko, A. Kuno, H. Kobayshi, and I. Kusakabe. 2000. Purification, characterization and gene cloning of two á-L-arabinofuranosidase from Streptomyces chartreusis GS901. Biochem. J. 346:9-15.

Morales, P., A. Madarro, A. Flors, J.M. Sendra, and J. A. Perez-Gonzalez. 1995. Purification and characterization of a xylanase and an arabinofuranosidase from Bacillus polymyxa. Enzyme Microbiol. Technol. 17:424-429.

Nigam, P. S. S. 2011. Production of liquid biofuels from renewable resources. Prog. Energ Combust. Sci. 37:52-68.

Prade, R. A. 1995. Xylanases from biology to biotechnology. Biotechnol Genet Eng Rev. 13: 101-131.

Ravanal, M. C., E. Callegeri and J. Eyazeguirre. 2010. Novel bifunctional á-L-arabinofuranosidase/xylibiohydrolase (ABF3) from Penicillium purpurogenum. Appl. Environ. Microbiol. 76 (15): 5247-53.

Rizzatti, A. C. S., V. C. Sandrim, J. A. Jorge, H. F. Terenzi and M. L. T. M. Polizeli 2004. Influence of temperature on the properties of xylanolytic enzymes of the thermotolerant fungus Aspergillus phoenicis. $J$ Ind Microbiol Biotech. 31:88-93.

Ronald, P. and V. Jaap. 2001. Aspergillus enzymes involved in degradation of plant cell wall polysaccharides. Microbiol Mol Biol Rev. 85(4):497-522.

Singh, S., B. Pillay, and B. A. Prior. 2000. Thermal stability of beta-xylanases produced by different Thermomyces lanuginosus strains. Enzyme Microb Technol. 26(7): 502-508.

Spano, L., T. Tassinari, D.D.Y. Ryu, A. Allen and M. Mandels. 1980. Producing ethanol from cellulosic biomass. Biogas and Alcohol Fuels Production 1:62-81 
Nepal Journal of Science and Technology Vol. 14, No. 2 (2013) 123-130

Taylor, L., and H. Bernard. 2006. A complete cellulase system in the marine bacterium Saccharophagus degradans strain 2-40. J. Bacteriol. 188:3849-3861.

Viikari, L., M. Tenkanen, J. Buchert, M. Ratto, M. Bailey and M. Siika-Apo. 1992. Hemicellulases for industrial applications. Biotechnology for Biofuels 4:131-182.

Wong, K. K. Y. and J.N. Saddler. 1986. Functional interactions among three xylanases from
Trichoderma harzianum. Enzyme Microb. Technol. 8:617-622.

Yan, Q., L. Tang, S. Yang, P. Zhuo, S. Zhang, and Z. Jiang. 2012. Purification and characterization of a novel thermostable á-1-arabinofuranosidase (á-1AFase) from Chaetomium sp. Process Biochemsitry 47(3): 472-478. 